\title{
Creativity and Rural Tourism
}

Jarábková Jana - Hamada Marián

\section{Abstract}

Purpose of the article The paper is seeking the mutual links between creativity, innovation and tourism in the rural areas. Creativity and innovation are often associated with cities, because the potential of creative industries and people is concentrated in cities. Is this assumption correct? Using examples from practice, this paper explains that creativity in tourism may be associated with the rural areas. Methodology/methods The contribution is linked with theoretical basis of creative economy under the research assignment APVV-0101-10 Creative economy - national economic and regional conditions and incentives. Therefore, it is based on analysis and comparison of views on possibilities for attracting the creative class to rural areas on one hand, and for development of creative activities within rural tourism on the other hand. Scientific aim The aim of the paper is to confirm the existence of real link between creativity, tourism and rural areas. Findings In the first part of the contribution, the basic terms as creativity, creative industry and creative class are explained and possibilities for their localization in rural areas are examined. Studies confirm that rural areas can become attractive environment for creative class despite problems like spatial diffusion of local resources and capacities and limited accessibility of capital. High-quality environment, attractive natural, cultural and historical potential and convenient infrastructure belong among the reasons for localization of creative class in rural areas. The same attributes are important for tourists who decide where to spend their free time. Conclusions Consequently, the support for development of rural tourism is understood in the paper as an instrument to improve the quality of places (municipalities) as well as to attract creative class and creative industries to rural municipalities. In the second part, the emphasis is put on definition of creative tourism as a creative industry based on creative activities. Examples of well-developed creative tourism in Europe are also given in this part, namely thematic routes connecting rural and urban municipalities, presenting them under certain theme issuing from local or regional culture and traditions.

Keywords: creativity, tourism, innovation, creative tourism, rural area

JEL Classification: L83, O18, O29 


\section{Definition of the term creativity}

The term creativity and its synonym inventiveness mean the ability to innovate an activity, to implement innovation from one geographical area or sector into another one or simply to bring something new, whether in a geographical area or a sector.

Economically speaking, creativity represented by an idea becomes an important production input such as capital or human work. Creativity is an unlimited resource and it is difficult to define. Standard economic rules are built on the premise that resources available to society are limited and precious. However, as an input factor, creativity shows us new economic rules and its influence cannot by predicted by standard models (Foundations for the concept promoting cultural and creative industry in the Slovak Republic, 2011). Taylor (1988) links creativity to the so called “4P”:

- the creative person

- the creative process

- the creative product

- the creative press (or the creative environment)

A creative idea is put into praxis in five stages:

1. Preparation, during which the creativity bearer deals with the issues that interest him, whether knowingly or unknowingly;

2. Incubation, when the bearer's subconscious mind produces ideas related to the issue. At this point, many surprising associations and ideas can come to life;

3. Comprehension, when the ideas come together like pieces of a puzzle;

4. Evaluation, during which the creativity bearer evaluates his ideas and thoughts and seeks their innovative elements;

5. Adaptation, when the ideas are put into praxis.

Creativity is not only difficult to define; it is also difficult to measure. According to Florida (2002a), creativity can be measured by the creativity index (3T) that consists of three parts: the talent index (including the human capital index and the creative class index), the technology index (innovation index, high-tech index) and the tolerance index (gay index, bohemian index and migration index).

Creativity is clearly manifested in areas that many authors call creative. According to the British Department for Culture, 'creative industry' is a sector based on human creativity, skill and talent. It uses intellectual property and therefore has potential for production of wealth and new jobs. Such sectors include advertising, architecture, art and antiquities market, arts and crafts, design, fashion, film and video, music, interpretative art, publishing, software, television and radio broadcasting, video and computer games and sports. Some approaches and documents, such as the Green Paper Unlocking the potential of cultural and creative industries (European Commission, 2010) claim tourism is one of the creative sectors. 


\section{Is there a real link between creativity, tourism and rural areas?}

Nowadays, creativity is usually associated with urban areas, mostly with metropolitan centres. The main sources of their economic growth are the creative people and sectors that are gathered here. According to Florida (2002b), creative people represent a creative class. Creative class consists of people who work in creative sectors (science and research, engineering, architecture, design, education, art, music and entertainment industry). The primary economic function of the creative class is to produce new ideas, technologies or new creative 'content'. Florida (2002c) adds three more sectors to the creative class: services, manual labour and fishery, agriculture and forestry. Florida claims that new entrepreneurial investments aim at places with high concentration of creative class members. On the other hand, creative individuals are often attracted to cities thanks to the notion of higher life quality (comfort) based on good community facilities, culture and cultural activities, potential for relax and recreation and other possibilities. This results in increasing investments into development of culture and tourism. These two are the competitive advantages of larger metropolitan centres. Although the creative sectors and the creative class seem to gather only in cities with ideal working and living conditions, many authors (Stolarick, K. - Denstedt, M. - Donald, B. - Spencer, G., 2010a) point out that rural areas have the potential for locating creative sectors and even rural municipalities can attract the creative class.

Rural areas also offer many of the above mentioned special conditions which attract the creative class to cities, such as good environment, culture or community facilities.

Some authors (Morgan, J. Q. - Lambe, W. - Freyer, A., 2009a) think that rural municipalities can use three strategic approaches to support their development. These approaches are based on their local development, economic development, creativity and talent.

The first approach is based on local specifics, cultural heritage, traditions and natural conditions. The development strategy results from the use of local resources for the development of tourism. Such municipalities have the atmosphere of peaceful places that offer authentic experiences and relax.

The second approach highlights the economic development by means of supporting entrepreneurial activities. Municipalities should create a business-friendly environment for local or starting entrepreneurs and support their activity.

The third approach emphasizes the need to support creativity and talent in rural municipalities and the advantages of such a support in terms of continuous economic growth. Creative economy in rural areas is based on the presence of art and culture. Morgan, J. Q., Lambe, W., Freyer, A. (2009b) claim that creativity-based municipal development is implemented via support of artistic talents, targeted support of arts and crafts courses and crafts and design training programmes.

For example, a municipality can involve talented artists in various projects aimed at organizing crafts courses or instructing local people and visitors. In exchange, the municipality will provide accommodation.

It is far more difficult to implement these development strategies in municipalities. Local development can be achieved by mobilization of local capacities (the economic, social, technological and political capacity) and resources (natural, economic and 
infrastructural). However, several problems arise - spatial diffusion of resources and capacities, limited amounts of the capital necessary for investments or too specific development strategies (for example, it aims at the development of tourism). While such a specific development strategy may be profitable from the short-term point of view, it does not take into account the long-term spillover effects.

Tourism is often used to solve problems resulting from changes in the economy structure, such as the decline in traditional rural sectors - agriculture and processing industry. Development of tourism gives rural municipalities an opportunity to create new jobs and to increase their economic activity. This instrument is often used by municipalities that do not have enough resources to finance their new aims or do not have alternative development opportunities. Development of rural tourism is based on the use of local resources (natural, cultural and historical potential) that motivate visitors to participate in tourism. Contemporary postmodern visitors look for authentic and unique experiences which rural areas can provide by making use of their resources. Adequate infrastructure is also an important factor in the development of rural tourism. Thematic routes are a good example of the revival and stimulation of economic growth that rural municipalities can manage. Thematic routes create the possibility to link various parts of natural, cultural and historical potential, to unite and present them under one theme, one brand. They stimulate entrepreneurial activity and development of new services for tourists. In Europe, there are many established cultural and sight-seeing routes but also wine routes (Wine Route Lower Austria, French Wine Routes and Saxon Wine Route), cheese routes (Schleswig-Holstein Cheese Route), milk and beer routes (Lower Saxony Milk Route, Aischgründer Bierstrasse). They mainly present the culture and gastronomy of chosen regions and countries.

\section{The creative class and rural areas}

Nowadays, creative class is a very important success factor in the economic development of municipalities and regions (Milotová, Chreneková, 2012). The quality of a place plays an important role in attracting and keeping the creative class. This quality is influenced by various factors such as community facilities, quality of environment, cultural life in the municipality, localization of relax and recreation facilities, consumer opportunities and so on. Many creative class members prefer places that offer authentic experiences and active lifestyle. Members of the creative class have different opinions on the quality of a particular place and they are not always concentrated in cities. McGranahan and Wojan (2007a) claim that creative class also gathers in the rural areas and it becomes the driving force of economic development. They support this theory with many arguments. They believe that the main reasons attracting the creative class to rural areas are the wealth of the country, low population density and good communication connections of a particular municipality. The authors even suggest that rural municipalities stimulate the growth of metropolitan centres, as they accommodate some groups of creative class members.

According to McGranahan and Wojan (2007b), creative class members move from metropolitan centres to rural areas. They are mostly attracted by municipalities from which they can commute to work in cities and those that are 'equipped' to represent lifestyle in the countryside. This trend can be found in the middle-aged and older generation of creative class members who are married and seek traditional rural lifestyle. 
Rural municipalities deal with many problems that result in the loss of human capital (young people leaving for cities, students going off to universities, graduates leaving for cities to find work). However, there is also an adequate alternative to solve these problems - attracting people who are interested in living in the countryside. McGranahan and Wojan (2007c) claim this group consists of middle-aged families, people changing their profession or seniors. Presenting the municipality as an attractive place for life with interesting natural, cultural and historical potential and adequate infrastructure (for education, health care and recreation) is essential in attracting potential residents (including creative class members). The authors suggest that creative class members are attracted to rural municipalities by the same attributes that attract tourists. Because of this, they suggest to develop rural municipalities using the same strategies that are implemented when developing tourism. This approach can ensure two desirable goals the municipality will attract creative class members and support the development of tourism at the same time.

Other authors (Stolarick, K. - Denstedt, M. - Donald, B. - Spencer, G., 2010b) claim that tourism is not merely a diversification tool in the economic structure of municipalities; it has a more important role in creating suitable conditions for attracting the creative class. This class creates innovations, new ideas, establishes new enterprises and stimulates localization of other enterprises into the municipality. It also gains a higher income than employees of the service sector or the primary sector. Attracting the creative class members can have continuous positive effects for municipalities. This class is not a monolithic group with the same requirements and needs and while some of its characteristics are the same, individuals and their families have various unique combinations of skills, possibilities and experiences that influence their choice of living place. Creating conditions improving the quality of life should therefore be directed at particular groups of creative class members whom the municipality wishes to attract. If the municipality succeeds in attracting creative class members, it should communicate with them, monitor their needs and support mutual cooperation.

\section{Based on this theory, rural tourism can be understood in two main contexts:}

\section{A tool increasing the quality of a place and attracting creative class and creative sectors to rural municipalities}

\section{A creative sector based on creative activities - the creative tourism}

\section{Creative tourism}

Creative tourism was mentioned for the first time as a potential form of tourism (Pearce a Butler, 1993). During the 90's, there was growing attention for creativity both in cities and rural areas. An example of this was the crafts tourism, as mentioned in the EUROTEX project undertaken in Finland, Greece and Portugal between 1996 and 1999. This project marked the growth of interest in local vernacular culture and everyday life. It also inspired the desire to participate through active creative learning experiences. This work resulted in defining creative tourism. 'Tourism which offers visitors the opportunity to develop their creative potential through active participation in courses and learning experiences which are characteristic of the holiday destination where they are undertaken' (Richards, G. 2011a). This concept was also accepted by the United Nations Educational, Scienti?c and Cultural Organization (UNESCO) Creative Cities Network, which produced its own de?nition: 'Creative tourism is travel directed toward an engaged and authentic experience, with participative learning in the arts, heritage, or special 
character of a place, and it provides a connection with those who reside in this place and create this living culture.' (UNESCO, 2006).

Raymond (2007) defines creative tourism as a sustainable form of tourism that offers authentic experiences of local culture using informal and practical seminars and creative experiences. Seminars take place in little groups in the households and workplaces of instructors. Visitors have the opportunity to discover their own creativity and get more involved with local people.

While each definition emphasizes a different point, they also have common elements: authenticity of experiences that enable visitors to develop their creative potential and their skills by means of contact with local people and their culture. Such a form of tourism prefers active consumption over passive consumption. It emphasizes life and intangible culture, not static tangible cultural heritage. Creative tourism is based on activities and experiences that offer self-realization and self-expression. Tourists thus become co-creators and develop their creative abilities.

\section{Figure 1: Creative tourism}
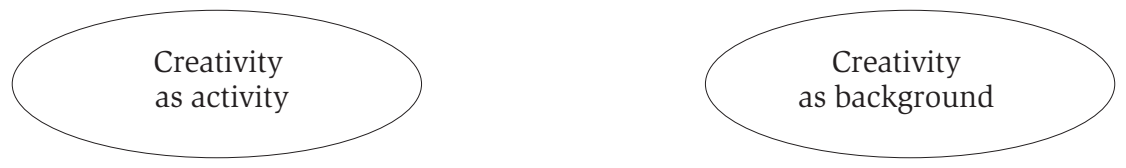

experiences and products
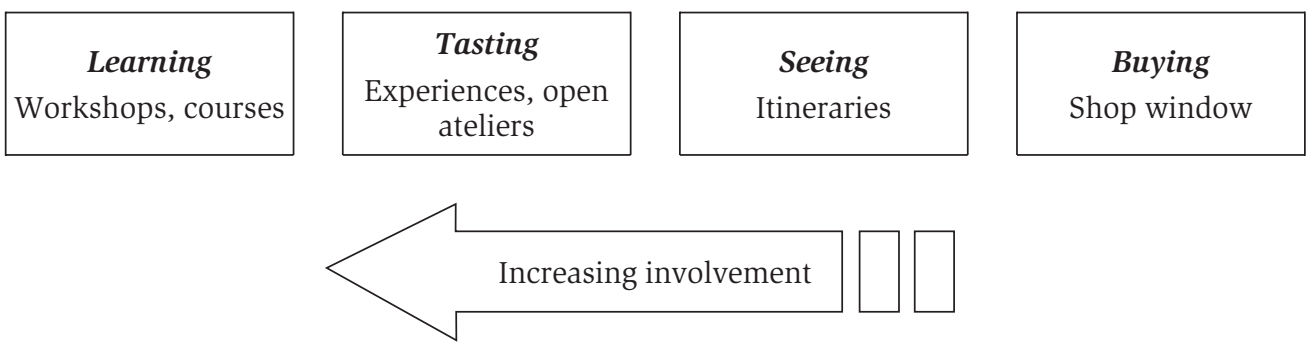

\section{Creativity bearers}
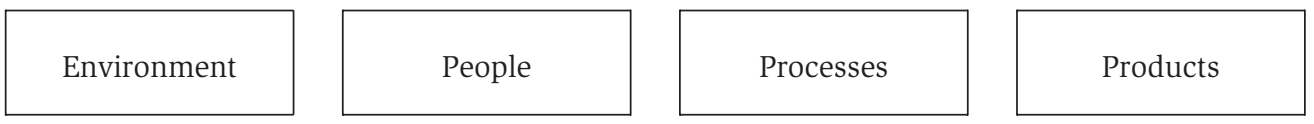

Source: Richards, G. 2011b. Creativity and tourism. The State of the Art. Modes of Creative Tourism. In: Annals of Tourism Research, Elsevier Ltd. Great Britain. No. 38 (2011), p. 1225-1253.

Richards and Raymond (2000) stress that not only tourists should be involved in creative activities but also the destination itself should offer typical experiences. It is inevitable to consider all creative aspects of a place that could attract creative tourists. Creativity is an important part of the target destination. Every target destination can offer a unique combination of knowledge, skills, tangible heritage, social capital and atmosphere that creates potential for particularly attractive creative activities. This 
uniqueness can be connected with local traditions such as pottery and wood carving or with cultural movements, events and so on.

Ohridska-Olson, R., Ivanov, S. (2010a) claim that there are two forms of creative tourism:

a) Creative tourism tied to a particular target destination. Following this approach, creative cities and municipalities are shaped. The image of creative cities and municipalities is used by tour operators to increase attractiveness when forming their products - holidays and tours.

b) Creative tourism based on creative activities. This approach follows the premise that products of creative tourism are spatially diffused and based on creative activities in which visitors can participate in various places independently of the location. For example, courses of Renaissance painting can be organized both in France and Italy.

In Europe, there are many examples of developed creative tourism. A very popular example is the evaluation of cultural and gastronomic heritage of the French rural areas by means of gourmet tourism. In French rural areas, the culture and gastronomy are represented by (Bessière, J., 1998):

- farms that sell fresh products to visitors either directly on the farm or on local markets, annual fairs or via consumer networks,

- farms that are willing to welcome visitors, offer them local food and drinks and use regional quality brands,

- family inns that offer accommodation and traditional food prepared from local products. They bear the quality brand Gîtes de France,

- 'holidays on farm' that include accommodation, cooking from fresh local products, eating at the family table, visiting farms and participating in free time activities,

- 'snacks at farms'- quickly prepared food from fresh agricultural products for the farm visitors,

- local gastronomic events such as local markets that offer local specialities (Bresse poultry), museum opening ceremonies (wine, cheese), special thematic routes (wine routes in Alsace or gastronomic routes in Drôme), cooking courses, visits to companies and factories (cheese production in the Roquefort company),

- traditional restaurants. For many chefs in the whole world, the regional French cuisine symbolizes the return to traditional cooking and traditional food.

Table 1 mentions other positive experiences with the use of local resources for creative tourism development in Bulgaria.

\section{Table 1: Examples of creative tourism development in Bulgaria}

\begin{tabular}{|l|l|l|}
\hline \multicolumn{1}{|c|}{ Location } & \multicolumn{1}{c|}{ Creativity base } & \multicolumn{1}{c|}{ Description of creative activity } \\
\hline Choprovtzi, Kotel & Local crafts & Carpet and fabric weaving \\
\hline Kazanluk & Rare ancient technologies & String instrument handcrafting classes \\
\hline Godech & $\begin{array}{l}\text { Gourmet food and local food } \\
\text { technologies }\end{array}$ & Yogurt making classes \\
\hline
\end{tabular}




\begin{tabular}{|l|l|l|}
\hline \multicolumn{1}{|c|}{ Location } & \multicolumn{1}{|c|}{ Creativity base } & \multicolumn{1}{c|}{ Description of creative activity } \\
\hline Karlovo & $\begin{array}{l}\text { Local technologies for herb } \\
\text { collection, essential oils and } \\
\text { perfume making }\end{array}$ & $\begin{array}{l}\text { Classes for herb collection and natural } \\
\text { cures in the Balkan Mountains, classes } \\
\text { of essential oil distillation and perfume } \\
\text { making }\end{array}$ \\
\hline Troyan & $\begin{array}{l}\text { Unique style of ceramics and } \\
\text { pottery design }\end{array}$ & $\begin{array}{l}\text { Ceramics and pottery making and design } \\
\text { classes }\end{array}$ \\
\hline Tryavna & Unique style of wood carving & Wood carving courses \\
\hline Chepelare & Traditional music & $\begin{array}{l}\text { Classes for traditional music instrument } \\
\text { playing, singing traditional Rhodope } \\
\text { songs, etc. }\end{array}$ \\
\hline
\end{tabular}

Source: Ohridska-Olson, R., Ivanov, S. (2010b). Creative Tourism Business Model and its Application in Bulgaria.

Interesting examples of creative tourism are the above mentioned thematic routes that link municipalities and cities in one route and present them under one theme. Their aim is to support creative tourism based on regional or local culture and traditions. One of the well established routes is the old salt route leading through Germany, the Czech Republic, Austria and Italy. It follows the tradition of salt mining and transport and the whole salt business. There are also castle and palace routes (Germany, France, Austria, the Czech Republic) that present the history of palaces, castles and ruins. Not only are these places static witnesses of history, they also become stages for open air plays, knight tournaments, historic markets or concerts. The German Fairy Tale Road (Deutsche Märchen Strasse) is also a very creative product. It includes places where the Brothers Grimm lived or where their stories took place, thus connecting art, history, beautiful regions with castles and palaces, typical old German towns with traditional architecture, museums, galleries, concerts, theatres and interesting events such as puppet theatre, the puppet days or the fairy tale week.

\section{Supporting creative tourism}

The tourism policy of the European Union creates various aims and instruments to support creative tourism development. It is one of the ways to confirm how extraordinary the European countries are, to improve the supply in tourism and to achieve important synergies with the arts and craft trades which can help to preserve the cultural heritage and develop local economies' (European Commission, 2010a).

Under the new political terms for European tourism as published by the European Commission in the above mentioned Communication from The Commission to The European Parliament, The Council, The European Economic and Social Committee and The Committee of the Regions, these are the main aims of the European policy on tourism:

1. Improving the competitiveness of European tourism

2. Supporting the development of continuous, responsible, first-rate tourism

3. Confirming the image of Europe as a complex of sustainable first-rate destinations 
4. Maximizing the potential of the European Union finance policies and instruments for tourism development.

All EU policies emphasize the need for unique and diverse supply in individual states and regions. This can be achieved by evaluating the thematic supply in Europe. Policy creators claim that such supranational products support advertising of tourism and include a whole range of heritage: cultural heritage, works of art, protected natural reserves, recreational tourism, educational tourism, gastronomy, sports, religion, rural tourism as well as industrial heritage or economic system of regions (European Commission, 2010b). The European Commission proposed a strategy supporting diverse touristic supply and better evaluation of common European heritage.

The work Foundations for the concept promoting cultural and creative industry in the Slovak Republic (Ministry of Culture of the Slovak Republic, 2011) mentions the support of Slovak creative tourism on the supranational level. This document identifies measures and instruments needed for support of creative economy. The authors recommend evaluating the instruments that support export, presentation of the Slovak Republic abroad and tourism in the scope of its relevance for creative industry. These are mainly investment stimuli and financial instruments. They should correspond with specific requirements of creative industry subjects such as low capitalization, the value of brand as property, high risks in the initial period, large influence of information technologies and irregular performance in the cultural industry sectors. The authors also suggest evaluating existing instruments of small and medium enterprises, for example simplifying the access to information about the financing possibilities, simplifying the process of submitting applications and their administration, creating possibilities for sponsors, creating partnerships of public and private financing and others.

\section{Conclusion}

In this article, we suggested that there is a real link between creativity, tourism and rural areas. We found out that many authors who pursue the concept of creative class think tourism is an instrument that helps to increase the quality of a location and to attract creative class and creative sectors to rural municipalities. They assume every municip ality tries to attract attention of the creative class because creative class brings many positive continuous effects - it creates innovation, generates new ideas, establishes and attracts new enterprises. Another approach emphasizes that tourism is one of the creative sectors as it is based on creative activities. The theories of tourism and practical politics started to use the term creative tourism. Its main features involve visitor's active participation in the creation of a product and authentic experiences including learning, art, cultural heritage and the special character of a particular place. There are many successful examples of creative tourism products, such as the popular thematic routes. For rural municipalities, the development of creative tourism brings many advantages (Ohridska-Olson, Ivanov 2010c): revival of local crafts and traditions, renewal of the local population's pride in their cultural heritage, preservation of tangible and intangible cultural heritage, creation of new jobs in creative sectors and income increase from such sectors, the spill-over effects of creativity, increase of competitiveness of the target destination. Even the European Commission stresses the need to develop creative tourism. In the new European tourism policies, The Commission suggested that the competitiveness of European tourism can be stimulated via unique and diverse supply of 
individual states and regions. They can achieve such a supply by using their cultural heritage.

This work was supported by the Slovak Research and Development Agency under the contract No. APVV-0101-10 .

\section{References}

Bessière, J., (1998). Local Development and Heritage: Traditional Food and Cuisine as Tourist Attractions in Rural Areas. Sociologia Ruralis. 1, pp. 21-34.

European Commission, (2010). GREEN PAPER: Unlocking the potential of cultural and creative industries.

European Commission, (2010a). Communication from The Commission to The European Parliament, The Council, The European Economic and Social Committee and The Committee of the Regions.

European Commission, (2010b). Communication from The Commission to The European Parliament, The Council, The European Economic and Social Committee and The Committee of the Regions.

Florida, R. (2002a). The Rise of the Creative Class: And How It's Transforming Work, Leisure, Community \& Everyday Life. New York: Basic Books.

Florida, R. (2002b). The Rise of the Creative Class: And How It's Transforming Work, Leisure, Community \& Everyday Life. New York: Basic Books.

Florida, R. (2002c). The Rise of the Creative Class: And How It's Transforming Work, Leisure, Community \& Everyday Life. New York: Basic Books.

McGranahan, D., Wojan, T. (2007a). Recasting the Creative Class to Examine Growth Processes in Rural and Urban Counties. Regional Studies, 41 (2), pp. 197 - 216.

McGranahan, D., Wojan, T. (2007b). Recasting the Creative Class to Examine Growth Processes in Rural and Urban Counties. Regional Studies, 41 (2), pp. 197 - 216.

McGranahan, D., Wojan, T. (2007c). Recasting the Creative Class to Examine Growth Processes in Rural and Urban Counties. Regional Studies, 41 (2), pp. 197 - 216.

Milotová, B., Chreneková, M. (2012). Creativity in the Countryside. International Scientific Conference „National and Regional Economics IX. „Herlany.

Ministry of Culture of the Slovak Republic. 2011. Foundations for the concept promoting cultural and creative industry in the Slovak Republic, 2011. [online] [Cited 2012-05-21] Available from

Internet http://eurlex.europa.eu/LexUriServ/LexUriServ.do?uri=COM:2010:0183:FIN:EN:PDF

Morgan, J. Q., Lambe, W., Freyer, A. (2009a). Homegrown Responses to Economic Uncertainty in Rural America Rural Realities, 3(2), pp. 1-15.

Morgan, J. Q., Lambe, W., Freyer, A. (2009b). Homegrown Responses to Economic Uncertainty in Rural America Rural Realities, 3(2), pp. 1-15.

Ohridska-Olson, R., Ivanov, S. (2010a). Creative Tourism Business Model and its Application in Bulgaria. [online] [Cited 2012-05-21] Available from Internet http://culturalrealms.typepad.com/files/creativetourismbm_article_1_lr.pdf

Ohridska-Olson, R., Ivanov, S. (2010b). Creative Tourism Business Model and its Application in Bulgaria. [online] [Cited 2012-05-21] Available from Internet http://culturalrealms.typepad.com/files/creativetourismbm_article_1_lr.pdf 
Ohridska-Olson, R., Ivanov, S. (2010c). Creative Tourism Business Model and its Application in Bulgaria. [online] [Cited 2012-05-21] Available from Internet

http://culturalrealms.typepad.com/files/creativetourismbm_article_1_lr.pdf

Pearce, D. G., \& Butler, R. W. (1993). Tourism research: Critiques and challenges. London: Routledge.

Raymond, C. (2007). Creative Tourism New Zealand: The practical challenges of developing creative tourism. In: G. Richards \& J. Wilson (Eds.), Tourism,creativity and development (pp. 145-157). London: Routledge.

Richards, G., Raymond, C. (2000). Creative tourism. ATLAS News, 23, pp. 16-20.

Richards, G. (2011a). Creativity and Tourism. The State of the Art. Modes of Creative Tourism. Annals of Tourism Research, 38, pp. 1225 - 1253.

Richards, G. (2011b). Creativity and Tourism. The State of the Art. Modes of Creative Tourism. Annals of Tourism Research , 38, pp. 1225 - 1253.

Stolarick, K. - Denstedt, M. - Donald, B. - Spencer, G., (2010a). Creativity, Tourism, Economic Development in a Rural Context: the Case of Prince Edward County. Working Paper Series: Martin Prosperity Research. pp. 1 - 21.

Stolarick, K. - Denstedt, M. - Donald, B. - Spencer, G., (2010b). Creativity, Tourism, Economic Development in a Rural Context: the Case of Prince Edward County. Working Paper Series: Martin Prosperity Research. pp. 1 - 21.

Taylor, C. (1988). Various approaches to and definitions of creativity. In: R. J. Sternberg (Ed.), The nature of creativity: Contemporary psychological perspectives (pp. 99-121).

UNESCO. (2006). Towards Sustainable Strategies for Creative Tourism Discussion. New Mexico.

\section{doc. Ing. Jana Jarábková, PhD.}

Department of Regional and Rural Development, Faculty of European Studies and Regional Development

Slovak University of Agriculture in Nitra

Tr. A. Hlinku 2, 94976 Nitra

Tel.: 037/6414567

jana.jarabkova@is.uniag.sk

\section{Ing. Marián Hamada}

Department of Regional and Rural Development, Faculty of European Studies and Regional Development

Slovak University of Agriculture in Nitra

Tr. A. Hlinku 2, 94976 Nitra

Tel.: 037/6414565

marian.hamada@is.uniag.sk 